\title{
The dependence on $\mathrm{Ca}^{2+}$ of the guanine-nucleotide-activated polyphosphoinositide phosphodiesterase in neutrophil plasma membranes
}

\author{
Shamshad COCKCROFT \\ Department of Experimental Pathology, School of Medicine, University College London, London WC1E 6JJ, U.K.
}

\begin{abstract}
The requirement for $\mathrm{Ca}^{2+}$ for the activation of polyphosphoinositide phosphodiesterase was studied with the guanine nucleotide analogue guanosine $5^{\prime}$-[ $\gamma$-thio]triphosphate $(\mathrm{GTP} \gamma \mathrm{S})$. Levels of $\mathrm{Ca}^{2+}$ that pertain in unstimulated neutrophils (100 nM) are obligatory for the full expression of enzyme activity stimulated with GTP $\gamma$ S. Reduction of $\mathrm{Ca}^{2+}$ to $1 \mathrm{~nm}$ leads to inhibition. Increasing the level of $\mathrm{Ca}^{2+}$ from $100 \mathrm{nM}$ to $1000 \mathrm{nM}$ does not alter enzyme activity. Guanosine $5^{\prime}$-[ $\beta$-thio]diphosphate (GDP $\beta$ S) does not stimulate the phosphodiesterase but is an effective inhibitor of activation by GTP $\gamma \mathrm{S}$. $\mathrm{Ca}^{2+}$ in the millimolar range can also activate the phosphodiesterase alone and this is not inhibited by GDP $\beta$ S. It is also shown that $\mathrm{Sr}^{2+}$ in the millimolar range can stimulate enzyme activity similarly to $\mathrm{Ca}^{2+}$.
\end{abstract}

\section{INTRODUCTION}

Stimulation of a wide variety of cells with their appropriate ligands leads to the generation of two signalling molecules, diacylglycerol and $\mathrm{IP}_{3}$, both derived from $\mathrm{PIP}_{2}$ hydrolysis (Berridge, 1984). $\mathrm{IP}_{3}$ is responsible for mobilizing $\mathrm{Ca}^{2+}$ from endoplasmic reticulum and diacylglycerol is the activator of protein kinase C (Berridge \& Irvine, 1984; Nishizuka, 1984). The enzyme responsible for causing the hydrolysis of the inositol lipids, polyphosphoinositide phosphodiesterase (PPI-pde), is present at the plasma membrane and is coupled to the receptor via a guanine nucleotide binding protein $\left(\mathrm{N}_{\mathrm{p}}\right)$ (Cockcroft et al., 1984; Cockcroft \& Gomperts, 1985; Lucas et al., 1985; Uhing et al., 1985, 1986).

Activation of neutrophils with fMet-Leu-Phe leads to stimulation of various functional responses including chemotaxis, oxidative burst and secretion of two populations of granules (Kreutzer et al., 1978; Bennett et al., 1980; Becker et al., 1985). Coupled to the activation of the functional responses is the stimulation of inositol lipid metabolism (Cockcroft et al., 1981, 1985; Volpi et al., 1983; Bradford \& Rubin, 1985; Di Virgilio et al., 1985) and a rise in cytosol $\mathrm{Ca}^{2+}$ (Pozzan et al., 1983; Lew et al., 1984). Studies of inositide metabolism in intact neutrophils have suggested that $\mathrm{Ca}^{2+}$ is required for the full expression of stimulated inositol lipid metabolism using fMet-Leu-Phe as the agonist (Cockcroft et al., 1980a,b, 1981; Cockcroft, 1984; Volpi et al., 1983; Di Virgilio et al., 1985).

The PPI-pde of neutrophil plasma membranes can be activated by $\mathrm{Ca}^{2+}$ in the millimolar range or by guanine nucleotides in the presence of $100 \mathrm{nM}-\mathrm{Ca}^{2+}$ (Cockcroft et al., 1984; Cockcroft \& Gomperts, 1985). In this paper the calcium requirement for the guanine-nucleotideactivatable PPI-pde is examined in an isolated plasma membrane preparation from human neutrophils. It is concluded that resting levels of $\mathrm{Ca}^{2+}$ that pertain in unstimulated cells (100 nM) are obligatory to support
PPI-pde activation in the presence of GTP $\gamma \mathrm{S}$ and a reduction in $\mathrm{Ca}^{2+}$ levels to $1 \mathrm{~nm}$ leads to a loss of activity. On the other hand, increasing the level of $\mathrm{Ca}^{2+}$ from $100 \mathrm{~nm}$ to $1000 \mathrm{nM}$ (the level attained in stimulated cells) does not influence the activity of the PPI-pde. It is also demonstrated that GDP $\beta$ S does not support activity of PPI-pde but is an effective inhibitor of GTP $\gamma$ S-activated, but not $\mathrm{Ca}^{2+}$-activated, PPI-pde.

\section{METHODS}

Human peripheral neutrophils were purified from buffy coat residues as described previously (Cockcroft, 1984). Neutrophils $\left(10^{8}\right.$ cells $\left./ \mathrm{ml}\right)$ were preincubated in a balanced salt solution comprising $137 \mathrm{~mm}-\mathrm{NaCl}$, $2.7 \mathrm{~mm}-\mathrm{KCl}, 1 \mathrm{~mm}-\mathrm{CaCl}_{2}, 1 \mathrm{~mm}-\mathrm{MgCl}_{2}, 20 \mathrm{~mm}-\mathrm{Hepes}$, $5.6 \mathrm{~mm}$-glucose, $1 \mathrm{mg}$ of bovine serum albumin $/ \mathrm{ml}$ and supplemented with $\left[{ }^{32} \mathrm{P}\right]$ phosphate $(100 \mu \mathrm{Ci} / \mathrm{ml})$ for $90 \mathrm{~min}$ at $37^{\circ} \mathrm{C}$ to prelabel the phospholipids including PIP and PIP $_{2}$. A light membrane fraction enriched in plasma membranes was prepared as described previously (Bennett et al., 1982). The plasma membrane fraction was suspended in $20 \mathrm{~mm}$-Pipes buffer containing $150 \mathrm{~mm}-\mathrm{KCl}$ and $100 \mu \mathrm{M}-\mathrm{EGTA}, \mathrm{pH} \mathrm{6.8}$, at a protein concentration of $1-2 \mathrm{mg} / \mathrm{ml}$. Samples $(100 \mu \mathrm{l})$ were transferred to tubes containing guanine nucleotides and various concentrations of $\mathrm{Ca}^{2+}$ buffered with EGTA ( 3 mM-EGTA final) or EGTA alone in an equal volume to give final concentrations as indicated. After $10 \mathrm{~min}$ at $37^{\circ} \mathrm{C}$, the reaction was quenched with acidified chloroform/methanol $(1: 2, \mathrm{v} / \mathrm{v})$. Lipid extraction, separation and quantification of polyphosphoinositides was as described previously (Cockcroft \& Gomperts, 1985). For the determination of the water-soluble inositol phosphates, the upper (aqueous) phase was neutralized, made up to $10 \mathrm{ml}$ with water and analysed on Dowex-1 (formate form) as described previously (Downes \& Michell, 1981). The formulations for the $\mathrm{Ca}^{2+}$-EGTA buffers were calculated as previously described (Barrowman et al., 1986a,b).

\footnotetext{
Abbreviations used: PPI-pde, polyphosphoinositide phosphodiesterase; GTP $\gamma$ S, guanosine $55^{\prime}-\left[\gamma\right.$-thio]triphosphate; GDP $\beta$ S, guanosine $5^{\prime}$ [ $\beta$-thio]diphosphate; PIP, PIP ${ }_{2}$, phosphatidylinositol 4-phosphate and 4,5-bisphosphate; $\mathrm{IP}_{2}, \mathrm{IP}_{3}$, inositol 1,4-bisphosphate and 1,4,5-trisphosphate.
} 

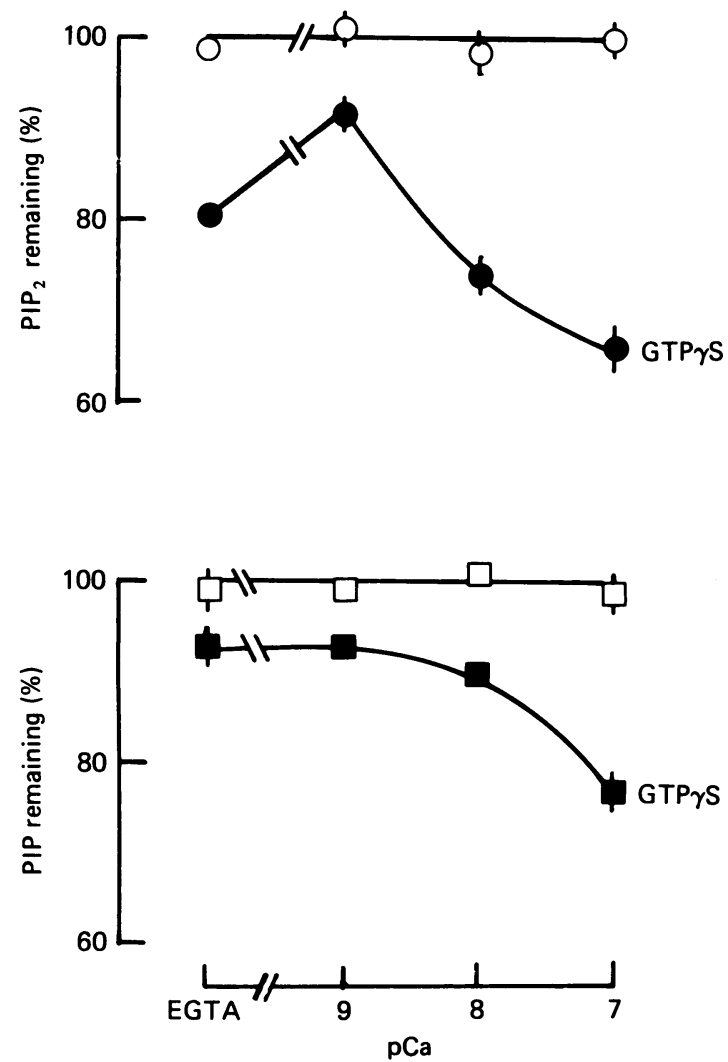

Fig. 1. $\mathrm{Ca}^{2+}$ dependence of GTP $\gamma \mathrm{S}$-induced polyphosphoinositide hydrolysis

${ }^{32} \mathrm{P}$-labelled neutrophil membranes were incubated for $10 \mathrm{~min}$ at $37^{\circ} \mathrm{C}$ in the presence of Ca-EGTA buffers (EGTA $3 \mathrm{~mm}$ ) to give the indicated free $\mathrm{Ca}^{2+}$ concentrations in the presence (closed symbols) or absence (open symbols) of GTP $\gamma \mathrm{S}(100 \mu \mathrm{M})$. The radioactivity in the presence of $3 \mathrm{mM}$-EGTA was designated as $100 \%$ and the remainder of the samples are expressed as a percentage of that. The data points presented are pooled from five individual experiments done either in triplicate or quadruplicate. The samples were quenched with acidified chloroform/methanol and the lipids extracted and analysed as described previously (Cockcroft et al., 1985).

\section{RESULTS}

\section{Calcium requirement of the GTP $\gamma \mathrm{S}$-stimulated PPI-pde}

The resting level of cytosol $\mathrm{Ca}^{2+}$ in neutrophils, as in other cells, is $120 \mathrm{~nm}$ (Pozzan et al., 1983). In previous studies it has been demonstrated that preincubation of neutrophils in the absence of external $\mathrm{Ca}^{2+}$ leads to the inhibition of fMet-Leu-Phe-stimulated inositol lipid metabolism (Cockcroft et al., 1980a,b, 1981; Cockcroft, 1984; Volpi et al., 1983; Di Virgilio et al., 1985). Here the $\mathrm{Ca}^{2+}$ requirement for the activation of the PPI-pde by GTP $\gamma \mathrm{S}$ in neutrophil membranes is demonstrated. Membranes were made from ${ }^{32} \mathrm{P}$-labelled neutrophils and incubated with GTP $\gamma \mathrm{S}(100 \mu \mathrm{M})$ in the presence of different concentrations of $\mathrm{Ca}^{2+}$ ranging from 1 to $100 \mathrm{nM}$ (buffered with 3 mM-EGTA). The hydrolysis of both PIP and PIP $_{2}$ was diminished as the level of $\mathrm{Ca}^{2+}$ was reduced from $100 \mathrm{~nm}$ to $1 \mathrm{~nm}$ (Fig. 1). Total inhibition of PIP ${ }_{2}$ hydrolysis was never observed in any experiment. In the presence of $3 \mathrm{~mm}$-EGTA alone, the percentage hydrolysis of $\mathrm{PIP}_{2}$ (but not PIP) was always greater than that at $1 \mathrm{nM}-\mathrm{Ca}^{2+}$. The decline in $\mathrm{PIP}_{2}$ and PIP with GTP $\gamma \mathrm{S}$ was matched by a corresponding increase in $\mathrm{IP}_{2}$ and $\mathrm{IP}_{3}$, showing that the loss was via a phosphodiesterase C-type cleavage as demonstrated previously (Fig. 2) (Cockcroft \& Gomperts, 1985). The $\mathrm{Ca}^{2+}$-dependency of $\mathrm{IP}_{2}$ and $\mathrm{IP}_{3}$ generation in the presence of GTP $\gamma \mathrm{S}$ is identical with the pattern observed for PIP and PIP $_{2}$ hydrolysis (Figs. 1 and 2).

We have recently shown that GTP $\gamma \mathrm{S}$ is able to cause secretion from permeabilized neutrophils in the presence of 3-30 mM-EGTA (Barrowman et al., 1986a). We argued that secretion due to GTP $\gamma \mathrm{S}$ was not due to activation of PPI-pde but due to activation of a guanine nucleotide regulatory protein $\left(\mathrm{N}_{\mathrm{e}}\right.$, distinct from $\left.\mathrm{N}_{\mathrm{p}}\right)$. Here it is shown that increasing the concentration of EGTA from $3 \mathrm{~mm}$ to $30 \mathrm{~mm}$ leads to a progressive loss of the GTP $\gamma \mathrm{S}$ activation of PIP ${ }_{2}$, but not PIP, hydrolysis
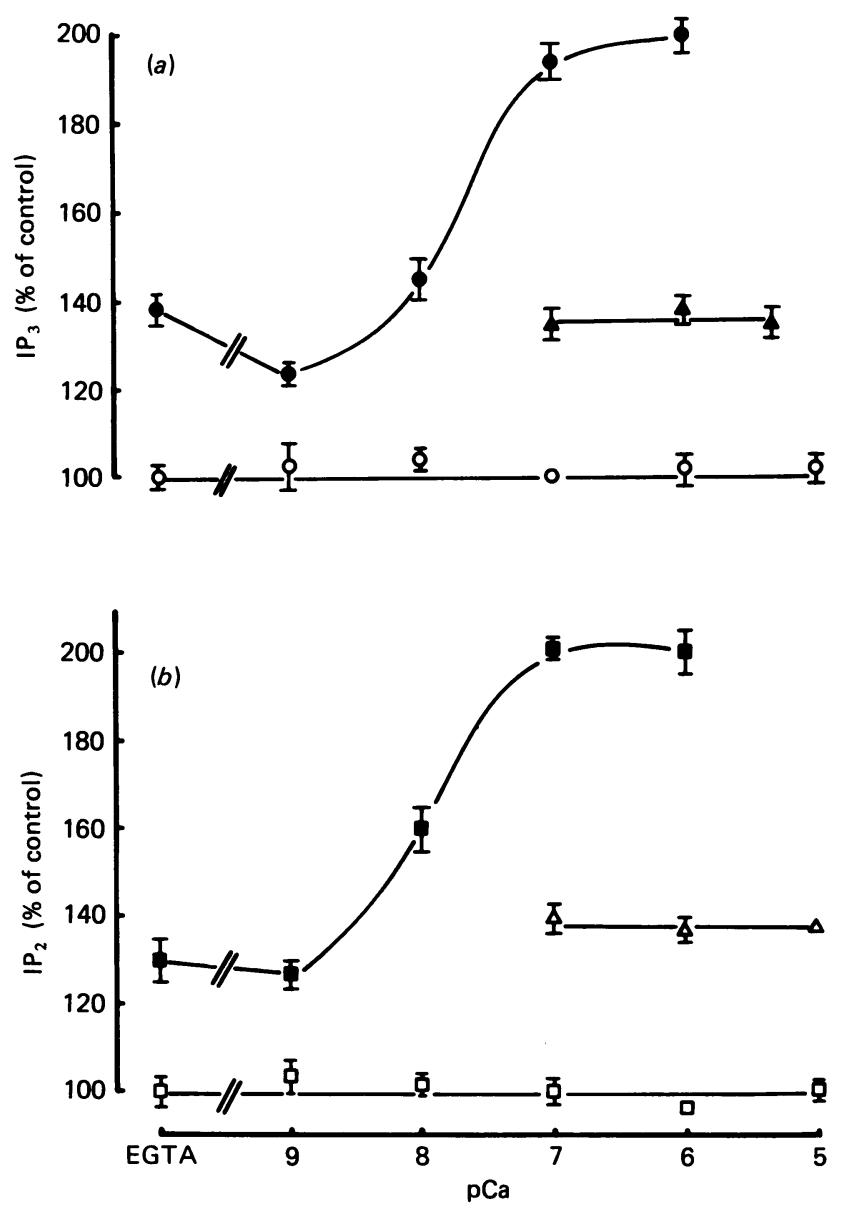

Fig. 2. $\mathrm{Ca}^{2+}$ dependence of $\mathrm{GTP} \gamma \mathrm{S}$-induced $\mathrm{IP}_{2}(a)$ and $\mathrm{IP}_{3}(b)$ formation

${ }^{32} \mathrm{P}$-labelled neutrophil membranes were incubated for $10 \mathrm{~min}$ at $37^{\circ} \mathrm{C}$ in the presence of $\mathrm{Ca}-\mathrm{EGTA}$ buffers (EGTA $3 \mathrm{~mm}$ ) to give the indicated free $\mathrm{Ca}^{2+}$ concentrations in the presence or absence of GTP $\gamma \mathrm{S}(10 \mu \mathrm{M}$ or $100 \mu \mathrm{M})$. The radioactivity in the $\mathrm{IP}_{2}$ and $\mathrm{IP}_{3}$ fractions in the presence of $3 \mathrm{~mm}-E G T A$ alone was designated as $100 \%$ and the remainder of the samples are expressed as a percentage of that. The results are an average of triplicate determinations \pm S.D. from a single experiment. $\bigcirc, \square$, Controls;,$\square$, GTP $\gamma \mathrm{S}(100 \mu \mathrm{M}) ; \Delta, \Delta, \mathrm{GTP} \gamma \mathrm{S}$ $(10 \mu \mathrm{M})$. 
Table 1. Effect of different concentrations of EGTA on the activation of PPI-pde by GTPyS

${ }^{32} \mathrm{P}$-labelled neutrophil membranes were incubated in the presence of various concentrations of EGTA in the presence or absence of GTP $\gamma \mathrm{S}(100 \mu \mathrm{M})$ for $10 \mathrm{~min}$. The experiment presented is typical of three others and the results are expressed as c.p.m. in PIP and PIP $_{2} \pm$ S.E.M. $(n=4)$.

\begin{tabular}{|c|c|c|c|c|c|c|}
\hline \multirow[b]{2}{*}{$\mathrm{EGTA}(\mathrm{mm})$} & \multicolumn{3}{|c|}{ PIP } & \multicolumn{3}{|c|}{$\mathrm{PIP}_{2}$} \\
\hline & $\begin{array}{l}\text { Control } \\
\text { (c.p.m.) }\end{array}$ & $\begin{array}{l}+\mathrm{GTP} \gamma \mathrm{S} \\
\text { (c.p.m.) }\end{array}$ & $(\%$ of control) & $\begin{array}{l}\text { Control } \\
\text { (c.p.m.) }\end{array}$ & $\begin{array}{l}+\mathrm{GTP} \gamma \mathrm{S} \\
\text { (c.p.m.) }\end{array}$ & $(\%$ of control $)$ \\
\hline $\begin{array}{r}3 \\
10 \\
30\end{array}$ & $\begin{array}{l}3609 \pm 195 \\
3506 \pm 90 \\
3660 \pm 271\end{array}$ & $\begin{array}{l}3590 \pm 94 \\
3672 \pm 131 \\
3796 \pm 84\end{array}$ & $\begin{array}{r}99 \\
105 \\
104\end{array}$ & $\begin{array}{l}3228 \pm 283 \\
3308 \pm 218 \\
3797 \pm 187\end{array}$ & $\begin{array}{l}2642 \pm 176 \\
2943 \pm 99 \\
3650 \pm 224\end{array}$ & $\begin{array}{l}82 \\
88 \\
96\end{array}$ \\
\hline
\end{tabular}

Table 2. Effect of $\mathrm{Ca}^{2+}$ on GTPyS-activated PPI-pde

${ }^{32} \mathrm{P}$-labelled neutrophil membranes were incubated with $\mathrm{Ca}^{2+}$ buffers in the presence and absence of GTP $\gamma \mathrm{S}$ (10 $\left.\mu \mathrm{M}\right)$. After 10 min of incubation the samples were quenched and processed as described in Fig. 1 legend. The experiment present is one of three and the results are presented as c.p.m. in PIP and PIP $_{2} \pm$ S.E.M. $(n=4)$, with percentages of control values in parentheses.

\begin{tabular}{cccccc}
\hline & \multicolumn{2}{c}{ PIP (c.p.m.) } & & \multicolumn{2}{c}{ PIP $_{2}$ (c.p.m.) } \\
\cline { 2 - 3 } $\mathrm{Ca}^{2+}(\mathrm{M})$ & Control & GTP $\gamma \mathrm{S}(10 \mu \mathrm{M})$ & & Control & GTP $\gamma \mathrm{S}(10 \mu \mathrm{M})$ \\
$10^{-7}$ & $10124 \pm 220(100)$ & $8435 \pm 390(83)$ & & $6529 \pm 59(100)$ & $5428 \pm 120(83)$ \\
$10^{-6}$ & $10595 \pm 213(100)$ & $8463 \pm 174(80)$ & & $6411 \pm 370(100)$ & $5396 \pm 183(84)$ \\
$10^{-5}$ & $10475 \pm 296(100)$ & $8407 \pm 204(80)$ & & $6685 \pm 418(100)$ & $5430 \pm 59(81)$
\end{tabular}

Table 3. Comparison between the effect of $\mathrm{Ca}^{2+}$ and $\mathrm{Sr}^{2+}$ on PPI-pde

${ }^{32} \mathrm{P}$-labelled neutrophil membranes were incubated in the presence of $\mathrm{Ca}^{2+}$ or $\mathrm{Sr}^{2+}(1 \mathrm{mM})$ for $10 \mathrm{~min}$ and the samples processed as in Fig. 1 legend. The results are expressed as c.p.m. in PIP and PIP $_{2} \pm$ S.E.M. $(n=3)$, with percentages of control values in parentheses.

\begin{tabular}{lll}
\hline & \multicolumn{2}{c}{${ }^{32}$ P (c.p.m.) in: } \\
\cline { 2 - 3 } & \multicolumn{1}{c}{ PIP } & \multicolumn{1}{c}{ PIP $_{2}$} \\
\hline Control & $5727 \pm 347(100)$ & $6612 \pm 550(100)$ \\
$\mathrm{Ca}^{2+}(1 \mathrm{mM})$ & $2689 \pm 68(47)$ & $3039 \pm 88(46)$ \\
$\mathrm{Sr}^{2+}(1 \mathrm{mM})$ & $4647 \pm 90(81)$ & $5103 \pm 67(77)$ \\
\hline
\end{tabular}

(Table 1). The level of PIP $_{2}$ recovered in the presence of $30 \mathrm{~mm}$-EGTA was always greater compared with $3 \mathrm{~mm}$ and this may reflect the ability of EGTA to chelate cations and so improve the extraction of PIP $_{2}$.

In stimulated neutrophils the level of $\mathrm{Ca}^{2+}$ rises from $120 \mathrm{nM}$ to $800 \mathrm{nM}$ (Pozzan et al., 1983). We therefore tested the effect of $\mathrm{Ca}^{2+}$ in the range $10^{-7}-10^{-5} \mathrm{M}$ in the presence and absence of $10 \mu \mathrm{M}-\mathrm{GTP} \gamma \mathrm{S}$ (Table 2). A submaximal dose of GTP $\gamma \mathrm{S}$ was chosen in order to study any potentiating effect of $\mathrm{Ca}^{2+}$ (Cockcroft \& Gomperts, 1985). $\mathrm{Ca}^{2+}$ up to $10 \mu \mathrm{M}$ is ineffective in stimulating PPI-pde as reported previously (Cockcroft et al., 1984) although there is a difference between the two sets of experiments. In the previous experiments the requirement for $\mathrm{Ca}^{2+}$ was studied under low ionic strength compared with the experiments presented here. It has been reported that ionic strength can modulate the requirement for $\mathrm{Ca}^{2+}$ for the activation of the PPI-pde in erythrocyte membranes (Downes \& Michell, 1982). Increasing the level of $\mathrm{Ca}^{2+}$ in the presence of a submaximal concentration of GTP $\gamma \mathrm{S}$ does not potentiate the activation of the PPI-pde (Table 2 and Fig. 2).

$\mathrm{Ca}^{2+}$ in the millimolar range alone is able to stimulate hydrolysis of polyphosphoinositides and this is accompanied by release of inositol phosphates and diacylglycerol (Cockcroft et al., 1984). $\mathrm{Ca}^{2+}$ in many instances

Table 4. Effect of GDPAS on GTP $\gamma \mathrm{S}-$ and $\mathrm{Ca}^{2+}$-induced polyphosphoinositide hydrolysis

${ }^{32} \mathrm{P}$-labelled human neutrophil membranes were suspended in buffer containing $100 \mathrm{nM}-\mathrm{Ca}^{2+}$ and transferred to tubes containing the appropriate additions as indicated. The results are presented as c.p.m. in PIP and PIP $_{2} \pm$ S.E.M. $(n=4)$ and are representative of two other experiments. Percentages of control values are given in parentheses.

\begin{tabular}{|c|c|c|}
\hline & \multicolumn{2}{|c|}{${ }^{32} \mathrm{P}$ (c.p.m.) in: } \\
\hline & PIP & $\mathbf{P I P}_{2}$ \\
\hline Control & $1931 \pm 126(100)$ & $1148 \pm 82(100)$ \\
\hline GTP $\gamma \mathrm{S}(100 \mu \mathrm{M})$ & $1390 \pm 63(72)$ & $752 \pm 15(65)$ \\
\hline $\begin{array}{c}\text { GTP } \gamma \mathrm{S}(100 \mu \mathrm{M})+ \\
\text { GDP } \beta S(1 \mathrm{mM})\end{array}$ & $1730 \pm 32(90)$ & $1063 \pm 30(93)$ \\
\hline $\mathrm{Ca}^{2+}(0.5 \mathrm{mM})$ & $1123 \pm 70(58)$ & $669 \pm 34(58)$ \\
\hline $\begin{array}{c}\mathrm{Ca}^{2+}(0.5 \mathrm{~mm})+ \\
\mathrm{GDP} \beta \mathrm{S}(1 \mathrm{mM})\end{array}$ & $1252 \pm 51(65)$ & $732 \pm 44(64)$ \\
\hline GDP $\beta S(1 \mathrm{~mm})$ & $1983 \pm 65(102)$ & $1178 \pm 14(102)$ \\
\hline
\end{tabular}


can be replaced partially by $\mathrm{Sr}^{2+}$ (Douglas \& Rubin, 1964; Foreman \& Mongar, 1972; Allan \& Thomas, 1981) and here it is shown that the $\mathrm{Ca}^{2+}$ activation of the PPI-pde can be mimicked by $\mathrm{Sr}^{2+}$ (Table 3).

\section{Inhibition of GTP $\gamma \mathbf{S}$ activation of PPI-pde by GDP $\boldsymbol{\beta S}$}

Activation of the PPI-pde by GTP $\gamma \mathrm{S}$ was inhibited by GDP $\beta$ S (Table 4). The inhibition was specific for GTP $\gamma$ S in that $\mathrm{Ca}^{2+}(1 \mathrm{mM})$-dependent activation of the PPI-pde was not inhibited by GDP $\beta$ S at the same concentration. GDP $\beta$ S alone had no effect on the PPI-pde (Table 4).

\section{DISCUSSION}

In this study it is demonstrated that optimal activation of PPI-pde in neutrophil membranes occurs with the stable guanine nucleotide analogue, GTP $\gamma \mathrm{S}$, when the level of $\mathrm{Ca}^{2+}$ is fixed at $100 \mathrm{nM}$ or above (see Fig. 1 and Table 2). This is the level of intracellular $\mathrm{Ca}^{2+}$ maintained in many cell types under physiological conditions (Tsien et al., 1982; Hallam et al., 1984; Thomas et al., 1984; Capponi et al., 1985). Reducing the $\mathrm{Ca}^{2+}$ level from $100 \mathrm{nM}$ to $1 \mathrm{nM}$ leads to the loss of PPI-pde activity in the membrane preparation. This result helps to reconcile the studies in the intact cell where $\mathrm{Ca}^{2+}$ deprivation led to a loss of the inositol lipid response (Cockcroft et al., 1980a,b, 1981; Cockcroft, 1984; Volpi et al., 1983; Di Virgilio et al., 1985). The $\mathrm{Ca}^{2+}$-dependency of the 'PI response' in the neutrophil did not quite fit in with the idea that inositol lipid metabolism was responsible for mobilizing $\mathrm{Ca}^{2+}$ (see Cockcroft, 1981; Michell et al., 1981, for discussion on this point). However, the earlier studies can now be reinterpreted. Incubation of cells, including neutrophils, in $\mathrm{Ca}^{2+}$-free media leads to a reduction in the resting cytosolic levels of free $\mathrm{Ca}^{2+}$ (Pozzan et al., 1983; Capponi et al., 1985; Tatham et al., 1986). It is possible that extensive depletion of intracellular $\mathrm{Ca}^{2+}$ had occurred during the prolonged incubations in $\mathrm{Ca}^{2+}$-free media in the experiments presented on neutrophils (Cockcroft et al., 1981). Thus it is more than likely that inhibition of fMet-Leu-Phe-stimulated secretion and inositol lipid metabolism in $\mathrm{Ca}^{2+}$-depleted cells was a consequence of the $\mathrm{Ca}^{2+}$-dependency of the PPI-pde.

Thus it is clear that the PPI-pde is a $\mathrm{Ca}^{2+}$-dependent enzyme but that its requirements are fulfilled by the presence of resting levels of cytosol $\mathrm{Ca}^{2+}$. Furthermore, the enzyme activity is not enhanced when cytosol $\mathrm{Ca}^{2+}$ is raised to the micromolar range, levels which occur in stimulated cells.

A guanine nucleotide-regulated PPI-pde has been identified in liver plasma membranes and was found to be dependent on $\mathrm{Ca}^{2+}$ in the nanomolar range (Uhing et al., 1985, 1986). On the other hand, the guanine nucleotide-regulated PPI-pde in GH3 cell membranes does not show an absolute dependence on $\mathrm{Ca}^{2+}$ but was enhanced when $\mathrm{Ca}^{2+}$ was greater than $10^{-9} \mathrm{M}$ (Lucas et al., 1985). Thus $\mathrm{Ca}^{2+}$ dependency of the PPI-pde may be general but may differ only in the level of sensitivity to the presence of $\mathrm{Ca}^{2+}$.

A somewhat unexpected result was the increase in PIP $_{2}$ loss when no $\mathrm{Ca}^{2+}$ was added to the preparation but 3 mM-EGTA was present. One possible explanation could be due to chelation of some heavy metal cation that releases its inhibitory effect on the PPI-pde. However, increasing the EGTA concentration from 3 to $30 \mathrm{~mm}$ led to a loss of PIP $_{2}$-pde activity. This result should be contrasted with the ability of GTP $\gamma$ S to cause secretion from permeabilized neutrophils in the presence of 30 mM-EGTA (Barrowman et al., 1986a). Both these observations taken together strongly support the proposal that another guanine-nucleotide regulatory protein (termed $\mathrm{N}_{\mathrm{e}}$ ) is involved in the exocytotic mechanism (Barrowman et al., 1986a; Gomperts et al., 1986).

GDP $\beta S$ has been shown to be an inhibitor of guanine nucleotide regulatory proteins, e.g. $\mathbf{N}_{\mathrm{s}}$, the activator of adenylate cyclase (Eckstein et al., 1979). Here it is shown that only activation by GTP $\gamma \mathrm{S}$ is inhibited by GDP $\beta$ S and not that induced by millimolar concentrations of $\mathrm{Ca}^{2+}$. This implies that activation by high concentrations of $\mathrm{Ca}^{2+}$ does not occur via a guanine nucleotide regulatory protein but by a direct effect either on the enzyme or on the substrate, which will bind $\mathrm{Ca}^{2+}$ (Buckley \& Hawthorne, 1972). It has been recently demonstrated that GDP $\beta$ S also inhibits the liver plasma membrane PPI-pde activated with GTP $\gamma \mathrm{S}$ (Uhing et al., 1986).

The work was supported by grants from the Medical Research Council and the Lister Institute. S.C. is a Lister Institute Research Fellow.

\section{REFERENCES}

Allan, D. \& Thomas, P. (1981) Biochem. J. 198, 441-445

Barrowman, M. M., Cockcroft, S. \& Gomperts, B. D. (1986a) Nature (London) 319, 504-507

Barrowman, M. M., Cockcroft, S. \& Gomperts, B. D. (1986b) J. Physiol. (London), in the press

Becker, E. L., Kermode, J. C., Naccache, P. H., Yassin, R., Marsh, M. L., Munoz, J. J. \& Sha'afi, R. J. (1985) J. Cell Biol. 100, 1641-1646

Bennett, J. P., Cockcroft, S. \& Gomperts, B. D. (1980) Biochim. Biophys. Acta 601, 584-591

Bennett, J. P., Cockcroft, S., Caswell, A. H. \& Gomperts, B. D. (1982) Biochem. J. 208, 801-808

Berridge, M. J. (1984) Biochem. J. 220, 345-360

Berridge, M. J. \& Irvine, R. F. (1984) Nature (London) 312, 315-320

Bradford, P. G. \& Rubin, R. P. (1985) Mol. Pharmacol. 27, 74-78

Buckley, J. T. \& Hawthorne, J. N. (1972) J. Biol. Chem. 247, 7218-7223

Capponi, A. M., Lew, P. D. \& Vallotton, M. B. (1985) J. Biol. Chem. 260, 7836-7842

Cockcroft, S. (1981) Trends Pharmacol. Sci. 2, 340-342

Cockcroft, S. (1984) Biochim. Biophys. Acta 795, 37-46

Cockcroft, S. \& Gomperts, B. D. (1985) Nature (London) 314, 534-536

Cockcroft, S., Bennett, J. P. \& Gomperts, B. D. (1980a) FEBS Lett. 110, 115-118

Cockcroft, S., Bennett, J. P. \& Gomperts, B. D. (1980b) Nature (London) 288, 275-277

Cockcroft, S., Bennett, J. P. \& Gomperts, B. D. (1981) Biochem. J. 200, 501-508

Cockcroft, S., Baldwin, J. M. \& Allan, D. (1984) Biochem. J. 221, 477-482

Cockcroft, S., Barrowman, M. M. \& Gomperts, B. D. (1985) FEBS Lett. 181, 259-263

Di Virgilio, F., Vicentini, L. M., Treves, S., Riz, G. \& Pozzan, T. (1985) Biochem. J. 229, 361-367

Douglas, W. W. \& Rubin, R. P. (1964) J. Physiol. (London) 175, 231-241

Downes, C. P. \& Michell, R. H. (1981) Biochem. J. 198, 133-140

Downes, C. P. \& Michell, R. H. (1982) Biochem. J. 202, 53-58 
Eckstein, F., Cassel, D., Lefkovitz, H., Lowe, M. \& Selinger, Z. (1979) J. Biol. Chem. 254, 9829-9834

Foreman, J. C. \& Mongar, J. L. (1973) Br. J. Pharmacol. 48, 527-537

Gomperts, B. D., Barrowman, M. M. \& Cockcroft, S. (1986) Fed. Proc. Fed. Am. Soc. Exp. Biol. 45, 2156-2161

Hallam, T., Thompson, N., Scrutton, M. \& Rink, T. (1984) Biochem. J. 221, 897-901

Kreutzer, D. L., O'Flaherty, J. T., Orr, W., Showell, H. J., Ward, P. A. \& Becker, E. L. (1978) Immunopharmacology 1, 39-47

Lew, P. D., Wollheim, C. B., Waldvogel, F. A. \& Pozzan, T. (1984) J. Cell Biol. 99, 1212-1220

Lucas, D. O., Bajjalieh, S. M., Kowalchyk, J. A. \& Martin, T. F. J. (1985) Biochem. Biophys. Res. Commun. 132, $721-728$

Received 14 May 1986/21 July 1986; accepted 20 August 1986
Michell, R., Kirk, C., Jones, L., Downes, C. \& Creba, J. (1981) Philos. Trans. R. Soc. London Ser. B 296, 123-138

Nishizuka, Y. (1984) Nature (London) 308, 693-698

Pozzan, T., Lew, D. P., Wollheim, C. B. \& Tsien, R. Y. (1983) Science 221, 1413-1415

Tatham, P. E. R., O'Flynn, K. \& Linch, D. C. (1986) Biochim. Biophys. Acta 856, 202-211

Thomas, A., Alexander, J. \& Williamson, J. (1984) J. Biol. Chem. 259, 5574-5584

Tsien, R., Pozzan, T. \& Rink, T. (1982) J. Cell Biol. 94, 325-334

Uhing, R. J., Jiang, H., Prpic, V. \& Exton, J. H. (1985) FEBS Lett. 188, 317-320

Uhing, R. J., Prpic, V., Jiang, H. \& Exton, J. H. (1986) J. Biol. Chem. 261, 2140-2146

Volpi, M., Yassin, R., Naccache, P. H. \& Sha'afi, R. I. (1983) Biochem. Biophys. Res. Commun. 112, 957-964 